\title{
Author: F Osman
}

\section{LEGI SLATI VE PROHI BITI ONS ON WEARI NG A HEADSCARF: ARE THEY J USTI FI ED?}

\section{ISSN 1727-3781}

2014 VOLUME 17 No 4 


\section{LEGI SLATI VE PROHI BITIONS ON WEARI NG A HEADSCARF: ARE THEY J USTI FI ED?}

\section{F Osman*}

\section{Introduction}

The Islamic headscarf, an innocuous piece of cloth worn by Muslim women in accordance with their religious beliefs, has for years been the subject of controversy. Muslim women claim a right to wear the headscarf in accordance with their religious beliefs while the Western world views the headscarf as a symbol of oppression and terrorism forced onto women by a patriarchal religion. The debate has grown in recent times with the increasing visibility of the Muslim population and their assertiveness of their Islamic identity and human rights. ${ }^{1}$

However, unlike other disputes regarding the compatibility of religious practices with modern values, the debate has not been confined to the private sphere to be resolved among members of the religion. States are embroiled in the debate and have gone so far as to enact legislation prohibiting the wearing of a headscarf. This article critically examines the reasons underlying these bans and argues that these prohibitions are not justified from any human rights perspective. Section 2 analyses the place of the headscarf in Islam, its religious basis and significance to Muslim women. Section 3 examines bans on the headscarf in France, Turkey and Switzerland in order to identify the most popular justifications advanced for banning the headscarf. Section 4 argues that the reasons advanced by many European states and accepted by courts for banning the headscarf do not justify a headscarf ban. Section 5 explores whether or not a headscarf ban would be upheld by South African courts.

Fatima Osman. B Bus Sci (Law), LLB, LLM (UCT). Admitted attorney and lecturer, Department of Private Law (University of Cape Town). Email: Fatima.Osman@uct.ac.za. Thank you to Prof Danwood Chirwa and Prof Debbie Collier for their comments on an earlier draft of this article.

1 McGoldrick Human Rights and Religion 1. 


\section{The headscarf and I slam}

The term "headscarf" refers to the head covering worn by Muslim women in accordance with their religious beliefs. It is generally worn to completely conceal a woman's hair, neck and ears, whilst leaving the face exposed. ${ }^{2}$ The obligation to wear a headscarf in Islam is derived from the Qur'an. The Qur'an states:

And say to the believing women that they should lower their gaze and guard their modesty, that they should not display their beauty and ornaments except that what must ordinarily appear thereof; that they should draw their veils over their bosoms and that they should not display their beauty except to their husbands, their fathers, their husbands' fathers, their sons, their husbands' sons, their brothers or their brothers' sons, or their sisters' sons, or their women or the slaves whom their right hands possess, or male servants free of physical needs, or small children who have no sense of the shame of sex and that they should not stroke their feet in order to draw attention to their hidden ornaments. ${ }^{3}$ [Emphasis added]

O Prophet! Tell thy wives and daughters, and the believing women, that they should cast their outer garments over their persons (when abroad). That is most convenient, that they should be known, (As such) and not molested. ${ }^{4}$ [Emphasis added]

While the preceding Qur'anic verses do not explicitly refer to a headscarf, they are generally interpreted to require Muslim women who have reached puberty to wear a headscarf when in public. Commentators of the Qur'an provide the context of the preceding Qur'anic verses. They explain that during the pre-Islamic era women would cover their hair but would tie the covering in such a way so as to leave the neck, ears and chest exposed. ${ }^{5}$ The command to cover the chest was therefore to compel women to now cover the neck, ears and breasts with the aim of protecting the modesty of women. ${ }^{6}$ The Qur'anic verses are also read in conjunction with the hadith ${ }^{7}$ in which it is reported that the Prophet Muhammad (may peace be upon

2 This article does not consider a legislative ban of the veil which conceals the face and leaves only the eyes exposed. While a ban on the veil may have similar implications for women who consider the veil to be obligatory, a veil raises distinct issues in respect of communication, the assessment of facial expressions and the recognition of individuals. This article examines the justifications for the ban of the far less restrictive headscarf.

Surah 24, Verse 31, reproduced in Ali Meaning of the Holy Qur'an 873-874.

Surah 33, Verse 59, reproduced in Ali Meaning of the Holy Qur'an 1077.

Madani Hijab 32.

Madani Hijab 32.

These are the recorded sayings or actions of the Prophet Muhammad (may peace be upon him). It is Islamic practice to confer peace and salutations on the Prophet Muhammad whenever his name is mentioned and this is why I have used the words "may peace be upon him". 
him) upon seeing Asma bint Abu Bakr wearing thin clothes indicated that upon reaching puberty a woman should cover her entire body except her hands and face when in public. ${ }^{8}$

Consequently, the four main schools of Islamic jurisprudence, ${ }^{9}$ which represent the dominant mainstream understanding of Islamic law, have interpreted the Qur'anic verses to mean that females upon reaching puberty are obliged to cover their heads in public. ${ }^{10}$ Historically, Muslim scholars have agreed that Muslim women are obliged to cover their heads in public and debate has revolved around whether Muslim women are also obliged to cover their face and hands in public. ${ }^{11}$

Accordingly, the general consensus amongst Muslim scholars is that the headscarf is obligatory in Islam. The obligation extends to all activities including work and school, and is not relaxed even for brief periods of physical activity. The headscarf should thus not be regarded merely as a religious symbol such as a cross worn by some Christians but rather understood as a mandatory requirement of the Islamic faith.

Furthermore, wearing a headscarf is also generally considered to be a manifestation of religion protected by the right to freedom of religion. The United Nations Human Rights Committee has stated that the observance and practice of religion includes, inter alia, the wearing of distinctive clothing or head coverings. ${ }^{12}$ This interpretation accords with the more recent jurisprudence of the European Court of Human Rights ("ECtHR") which has in Dahlab v Switzerland ${ }^{13}$ and Sahin v Turkey ${ }^{14}$ assumed that wearing a headscarf is a religious practice and decided both cases on the basis of whether the interference with religious freedom was justifiable. South Africa, ${ }^{15}$ like

8 ad-Darsh Muslim Women's Dress 7-8. Some scholars consider this hadith to be weak and unreliable and argue that women are obliged to cover their faces and hands when in public.

$9 \quad$ The four schools, being Shafi'i, Hanafi, Maliki and Hanbali, represent different schools of thought on the interpretation of religious material and are named after the Muslim jurists who founded the school of thought.

10 ad-Darsh Muslim Women's Dress 8; Ahmad Encyclopaedia of Islamic Jurisprudence 351-359; Mutahhari Islamic Modest Dress 51-55.

11 Mutahhari Islamic Modest Dress 59-71; Madani Hijab xv.

12 CCPR General Comment No 22: Article 18 (Freedom of Thought, Conscience or Religion) CCPR/C/21/Rev1/Add4 (1993) para 4.

13 Dahlab v Switzerland Application No 42393/98 ECHR (2001) (hereafter Dahlab v Switzerland).

14 Leyla Sahin v Turkey (Application 44774/98) 45 ILM 436 (2006) (hereafter Leyla Sahin v Turkey).

15 MEC for Education, KwaZulu Natal v Pillay 20081 SA 474 (CC) (hereafter MEC for Education $v$ Pillay). 
the United States of America, ${ }^{16}$ Canada $^{17}$ and Germany, ${ }^{18}$ adopts a subjective test for determining whether conduct constitutes a protectable manifestation of religion. The subjective test protects conduct based on sincerely held religious beliefs and does not require claimants to prove that the conduct is an objective requirement of their religion. This means that, in the absence of real evidence that a claimant is acting fraudulently, wearing a headscarf would be protected by religious freedom in these jurisdictions.

Accordingly, any assessment as to the justifiability of a headscarf ban must take cognisance of the fact that the headscarf is regarded as a mandatory requirement of the Islamic faith and generally considered to be protected by the right to freedom of religion.

\section{Legislative bans of the headscarf}

\subsection{France}

In France, the debate regarding the banning of the headscarf began in 1989 when a school suspended 3 Muslim girls for wearing headscarves to school. ${ }^{19}$ The debate culminated in the 2004 French law prohibiting students in public schools from wearing clothing manifesting a religious affiliation ${ }^{20}$ (hereinafter referred to as "the French Headscarf Ban"). The French Headscarf Ban states:

In public elementary, middle and high schools, the wearing of signs or clothing which conspicuously manifest students' religious affiliations is prohibited. Disciplinary procedures to implement this rule will be preceded by a discussion with the student. The clothing and religious signs prohibited are conspicuous signs such as a large cross, a veil or a skullcap. Not regarded as signs indicating religious affiliation are discreet signs, which can ... be medallions, small crosses, stars of David, hands of Fatima, or small Korans. ${ }^{21}$ [Emphasis added]

\footnotetext{
16 Thomas $v$ Review Board of the Indiana Employment Security Division 45 US 707. Syndicat Northcrest v Amselem [2004] 2 SCR 551.

Von Campenhausen 2004 BYU L Rev 678, which discusses the German Federal Constitutional Court's approach of determining if a practice is protected by religious freedom by looking at the subjective beliefs of the claimant and not the general and universal requirements of the religion.

19 Beller 2003-2004 TILJ 582-583.

$20 \quad$ Welch 2007 Denning LJ 201.

21 Barbibay 2010 CJICL 177-178.
} 
The Stasi Commission, which had been commissioned to report on issues associated with laïcité, recommended a headscarf ban along with a number of other measures to protect laïcité. 22 However, only the headscarf ban was enacted. Laïcité is the French constitutional principle that requires the public sphere to be neutral and religion and all manifestations thereof to be confined to the private sphere. ${ }^{23}$ French politicians explained the law on the basis of protecting laïcité and maintaining the secular nature of state schools. ${ }^{24}$ Weil, ${ }^{25}$ a member of the Stasi Commission, furthermore explained the ban as being necessary to prevent Muslim girls from being coerced by their families and communities into wearing headscarves. In support of this, Weil ${ }^{26}$ stated that teachers and parents described an unmanageable situation at schools with girls being removed from public schools to avoid the pressure to wear a headscarf. According to Weil, ${ }^{27}$ the majority of Muslim girls who did not wear a headscarf in fact requested the headscarf ban to protect against such pressure.

Interestingly, Weil ${ }^{28}$ emphatically stated that the Stasi Commission did not recommend the ban because it viewed the headscarf as a symbol of the subjugation of women and explained that such an interpretation could not justify banning the headscarf. Weil ${ }^{29}$ conceded that the headscarf may have different meanings, such as being an expression of belief and identity, ${ }^{30}$ and banning the headscarf because it symbolises the subjugation of women would constitute "an intrusive interpretation of a religious symbol" which may infringe on state neutrality in respect of religion.

22 Bowen Why the French Don't Like Headscarves 112-113.

23 Bienkowski 2010 RJLR 439; for a detailed discussion on the meaning of laïcité see Idriss 2005 Legal Studies 260-263.

24 Boustead 2007 J Transnat'l L \& Pol'y 189.

25 Thomas 2005 Dialectical Anthropology 382-383; see also Idriss 2005 Legal Studies 277.

Weil 2009 Cardozo L Rev 2707.

Weil 2009 Cardozo L Rev 2707.

Weil 2009 Cardozo L Rev 2705-2706.

Weil 2009 Cardozo L Rev 2705-2706.

For different interpretations of the headscarf also see Zhurnalova Religion in the Public Sphere 298-299; McGoldrick Human Rights and Religion 61; and Poulter 1997 OJLS 71. 


\subsection{Turkey}

A headscarf ban is nowhere more surprising than in the predominantly Muslim country of Turkey. The Atatürk revolution in the 1920s saw the end of Islamic rule in Turkey and the start of a concerted state attempt to eradicate traditional Islamic symbols, which were seen as a threat to a modern and secular Turkey, from the public sphere. ${ }^{31}$ Accordingly, state regulation of religious dress is not new in Turkey but was brought to the fore when Leyla Sahin challenged the controversial regulations prohibiting university students from wearing headscarves during classes in the ECtHR. ${ }^{32}$ The ban was based on the Istanbul University regulations stating that:

By virtue of the Constitution, the law and regulations, and in accordance with the case law of the Supreme Administrative Court and the European Commission of Human Rights and the resolutions adopted by the university administrative boards, students whose "heads are covered" (who wear the Islamic headscarf) and students (including overseas students) with beards must not be admitted to lectures, courses or tutorials. 33 [Emphasis added]

The ban, which was upheld by the ECtHR, ${ }^{34}$ targeted the headscarf and was aimed at students in tertiary institutions, but has not been enforced since about September 2010 when Turkey indicated that "it would support any student disciplined or expelled for covering her head". ${ }^{35}$

Leyla Sahin was a fifth-year medical student who was refused access to examinations and lectures on her enrolment at Istanbul University on the basis that she wore a headscarf in contravention of the regulations. ${ }^{36}$ The ECtHR endorsed the approach of its Chamber, which held that the ban was necessary to preserve secularism, protect the equality rights of women and combat extremist political

\footnotetext{
$31 \quad$ Bleiberg 2005-2006 Cornell L Rev 131.

Leyla Sahin $v$ Turkey.

Leyla Sahin v Turkey 438 para 16.

Leyla Sahin $v$ Turkey.

Head 2010 http://www.bbc.co.uk/news/world-europe-1180622.

Leyla Sahin v Turkey 438 para 17. Sahin initially studied at Bursa University, enrolled at Istanbul University in 1997 during her fifth year, and claimed she had been wearing a headscarf during her 4 years at Bursa University, Leyla Sahin v Turkey 438 para 15.
} 
movements which wished to impose on society their religious symbols and conception of a society founded on religious precepts. ${ }^{37}$

The ECtHR held that the principle of secularism was the paramount consideration underlying the headscarf ban and held:

In such a context, where the values of pluralism, respect for the rights of others, and in particular, equality before the law of men and women are being taught and applied in practice, it is understandable that the relevant authorities should wish to preserve the secular nature of the institution concerned and so consider it contrary to such values to allow religious attire, as in the present case, the Islamic headscarf, to be worn. ${ }^{38}$

The ECtHR also suggested that the Islamic requirement that women wear a headscarf and the headscarf itself were inconsistent with the value of equality. The ECtHR endorsed its previous findings in Dahlab v Switzerland ${ }^{\beta 9}$ in which it held that: [the headscarf] appeared to be imposed on women by a religious precept that was hard to reconcile with the principle of gender equality. It also noted that wearing the Islamic headscarf could not easily be reconciled with the message of tolerance, respect for others and, above all, equality and non-discrimination that all teachers in a democratic society must convey to their pupils. ${ }^{40}$

The judgment, however, did not elaborate on why or how the headscarf conflicts with equality, tolerance or respect for others or how the ban could curb extremism. Judge Tulkens, in a minority judgment, delivered an astute critique of the majority judgment which questioned how the majority simply accepted that the ban was necessary to protect secularism or achieve equality without explaining why or how this is so. Judge Tulkens stated that by simply assuming that the headscarf conflicts with secularism when there was no evidence to this effect, the majority placed its own interpretation upon the headscarf, which was unacceptable. ${ }^{41}$ The majority's evaluation of wearing a headscarf as a negative practice, which led to its upholding the ban, was criticised as an improper paternalistic approach, and Judge Tulkens

Leyla Sahin v Turkey 453-4 para 115.

Leyla Sahin v Turkey 454 para 116.

Dahlab v Switzerland.

Leyla Sahin v Turkey 452-3 para 111.

Leyla Sahin v Turkey, dissenting opinion of judge Tulkens 462-464 paras 7-12. 
noted that the principle of sexual equality could never justify prohibiting a woman from following a freely adopted practice. ${ }^{42}$

\subsection{Switzerland}

A headscarf ban may also be aimed at public officials and prohibit employees from wearing a headscarf whilst performing their professional duties. A prominent example of this is the case of Dahlab $v$ Switzerland, ${ }^{43}$ in which Swiss educational authorities prohibited a primary school teacher from wearing a headscarf while teaching.

Switzerland successfully defended its prohibition on wearing a headscarf in the ECtHR. The state relied on certain seemingly neutral statutory provisions which did not explicitly prohibit the headscarf but were argued to provide general values to which civil servants should adhere and which could be translated into specific orders, ${ }^{44}$ such as banning the headscarf. The state argued that the prohibition was meant to protect the principle of "denominational neutrality in schools" and to promote "religious harmony". 45 The state argued that Dahlab as a civil servant was a representative of the state and her conduct should not suggest that the state endorsed a particular religion. ${ }^{46}$ The ECtHR held that the prohibition pursued the legitimate aims of protecting the rights and freedoms of others, public safety and public order, ${ }^{47}$ and seemed to implicitly accept that the prohibition was necessary to protect religious harmony and neutrality.

A further critical aspect of the case was the young ages of the pupils taught by Dahlab. Dahlab taught pupils aged between four and eight and the ECtHR held that the prohibition on teachers wearing a headscarf was necessary to prevent the

Leyla Sahin v Turkey, dissenting opinion of judge Tulkens 462-464 paras 7-12.

Dahlab v Switzerland.

"The public education system shall ensure that the political and religious beliefs of pupils and parents are respected" and "Civil servants must be lay persons; derogations from this provision shall be permitted only in respect of university teaching staff." Ss 6 and 12 Canton of Geneva Public Education Act of 6 November 1940 as cited in Dahlab v Switzerland 4-5.

45 Dahlab v Switzerland 11.

46 Dahlab v Switzerland 11-12.

$47 \quad$ Dahlab v Switzerland 14. 
coercion of young children. ${ }^{48}$ It was assumed, without any evidence in support thereof, that the mere wearing of a headscarf could have a proselytising effect on young children, which needed to be curbed. As previously stated, the ECtHR also considered the wearing of the headscarf to be incompatible with the principle of gender equality as the Qur'an imposes it on women only, and found that the prohibition might be necessary to protect gender equality. ${ }^{49}$

\section{Justifications for a headscarf ban}

The aforegoing analysis of prominent headscarf bans reveals that there are four main justifications for banning the headscarf, namely protecting secularism, preventing coercion, promoting equality and guarding against religious extremism. This section evaluates the veracity of these justifications and whether or not they indeed support a headscarf ban. ${ }^{50}$

\subsection{Secularism}

The protection of secularism is perhaps one of the most popular justifications advocated by states and accepted by courts for banning the headscarf. Secularism is generally thought to be the separation of religion and state, a principle that requires the state to be neutral with respect to religion and not to promote a religious, or irreligious, point of view. The state is seen as an "impartial organiser" of the exercise of religion, which does not assess the legitimacy of religious beliefs or the way in which they are expressed. ${ }^{51}$ The impartiality of the state is thought to be important to prevent the abuse of state power and to ensure that dominantly practised religions are not favoured at the expense of minority religions. There is, however, some disagreement as to how strict the separation between religion and the state should be, and what is required in order to achieve state neutrality.

Dahlab v Switzerland 15.

Dahlab v Switzerland 15.

This article does not examine other peripheral justifications for banning the headscarf such as protecting the health and safety of individuals wearing the headscarf or maintaining discipline at schools, as these are not frequently relied upon by states and courts.

51 Leyla Sahin $v$ Turkey 450 para 107. 
The liberal interpretation of secularism requires a separation of religion and state but allows manifestations of religion in the public sphere. ${ }^{52} \mathrm{It}$ accords with the idea of passive neutrality in which the state does not support any religion but refrains from passing laws that inhibit the practice of religion. Religious symbols in public institutions, including schools, are allowed and tolerance of different beliefs is promoted. ${ }^{53}$ The neutrality of the state is that it neither prescribes nor prohibits the manifestation of religion but merely allows the expression of religious beliefs without any assessment as to the legitimacy of the beliefs. The public manifestation of belief, such as wearing a headscarf, ${ }^{54}$ is allowed but may of course be restricted with legitimate reasons. It should thus be clear that in terms of the liberal interpretation of secularism, it is not the principle of secularism per se that requires or can justify a headscarf ban.

The strict interpretation of secularism goes beyond the separation of religion and state and relegates religion and all manifestations thereof to the private sphere. It requires the public sphere to remain absolutely neutral and prohibits all public manifestations of religion by public officials or by citizens in public institutions. ${ }^{55}$ The state is entitled to actively protect secularism by legislating against public manifestations of religion. The strict separation of state and religion is argued to eliminate ethnic differences between citizens and to create a single national identity into which all citizens can assimilate ${ }^{56}$ with the aim of promoting greater social cohesion in society ${ }^{57}$ and avoiding conflict. The absence of any religious manifestations is also meant to protect individuals against pressure from religious groups and proselytism. ${ }^{58}$

The strict interpretation of secularism is problematic for faiths like Islam, which is often referred as more than just a religion but as a way of life. Islam prescribes a comprehensive code of conduct for every aspect of a Muslim's life. It provides

\footnotetext{
52 Plesner "European Court on Human Rights" 2.

53 Nathwani 2007 NQHR 228.

$54 \quad$ Nathwani 2007 NQHR 229.

55 Plesner "European Court on Human Rights" 3. This strict interpretation of secularism accords with the French principle of laïcité.

56 Bienkowski 2010 RJLR 437.

57 Poulter 1997 OJLS 47.

58 McGoldrick Human Rights and Religion 13.
} 
detailed regulations not only for what Muslims may eat and wear but also regarding marriage, inheritance, the punishment of crimes and commercial dealings. Islam accordingly attempts to regulate every aspect of a Muslim's life both in the public and the private sphere and is hard to reconcile with the notion that religion and all manifestations thereof are to be confined to the private sphere.

Furthermore, the rationale for strict religious neutrality is attractive, but the consistency of the argument is questionable. While states often advocate banning the headscarf to maintain secularism, these bans often evince a real entanglement between state and religion rather than a separation thereof. This entanglement is most obvious in prohibitions on religious dress which allow exceptions for certain religions. For example, some German states have enacted controversial laws prohibiting religious symbols in classrooms but allow exceptions for Christian dress. ${ }^{59}$ These laws blatantly discriminate between religions and favour Christianity but have been upheld on the basis that Christian values are universal values which inform the values of the German Basic Law and to which public officials can adhere regardless of their religion. ${ }^{60}$ The idea, however, that Christian values are universal values is problematic and reflects a Western point of view which most non-Christians would reject. Such laws furthermore do not promote neutrality but in fact favour and reenforce Christianity as the dominantly practised religion at the expense of minority religions. This is unfair as it prohibits Muslim school teachers from wearing a headscarf while teaching but their Christian counterparts, who enjoy an exception to the prohibition, may wear a nun's habit.

Even seemingly neutral laws may display an unacceptable though more nuanced state involvement with religion. So for example the French Headscarf Ban, which is couched in neutral terms, was commonly understood to be aimed at preventing Muslim girls from wearing the headscarf to school. ${ }^{61}$ The headscarf is considered to be contrary to French values, which are based on Judaeo-Christian values. ${ }^{62}$ But a state's assessment as to the legitimacy of a practice and whether it should be

\footnotetext{
59 Lock "Of Crucifixes and Headscarves" 361.

60 Fogel 2006-2007 NYL Sch L Rev 640.

61 Barbibay 2010 CJICL 178.

62 Boustead 2007 J Transnat'l L \& Pol'y 169-170.
} 
allowed based on its own religious values reveals a real state involvement with religion rather than religious neutrality. The French Headscarf Ban is an example of a well-crafted law which targets minority religious practices but leaves the favoured religion unaffected.

Similarly, Turkey's headscarf ban is about controlling and regulating the practice of Islam. Recently Turkey has allowed greater public manifestations of traditional Islam, ${ }^{63}$ but historically the state has been staunchly secular and has treated Islamic conservatism as a threat to the secular state. The state has dealt with this threat by controlling and suppressing the practice of traditional Islam in Turkey by regulating Islamic education, mosques, the sermons delivered at Friday mosque prayers, ${ }^{64}$ and even political parties. ${ }^{65}$ The reality is that the Turkish state is heavily involved with religion and uses the guise of secularism to coerce women to forgo the traditional headscarf and adopt the more modern state version of Islam.

It is furthermore questionable that the requirement of state neutrality can be imposed on public officials. Zhurnalova ${ }^{66}$ notes that neutrality is a requirement of the state and is not an obligation imposed on individuals such as public officials. The neutrality requirement should not be extended to individuals simply because they are employed by the state, nor should the conduct of state employees be automatically attributed to the state. ${ }^{67}$ It is even more difficult to impose the requirement of neutrality onto students who do not represent the state but merely

63 Most outstanding and noteworthy is Turkey's repeal of a prohibition on headscarves in public institutions which dates back to 1925, AFP $2013 \mathrm{http} / / / \mathrm{www}$.aljazeera.com/news/europe/2013/ 10/turkey-lifts-decades-old-ban-headscarves-201310814177943704.html.

64 Bleiberg 2005-2006 Cornell L Rev 154.

65 In 1998 the Turkish Constitutional Court went so far as to dissolve the Turkish political party, Refah Partisi, which was part of a coalition government at the time, on the basis that its members had endangered the principle of secularism. This drastic measure was in response to acts of members which included amongst others changing public service working hours to accommodate fasting in Ramadaan and receiving religious leaders at the Prime Minister's residence. While the judgment has been severely criticised as being completely disproportionate to the impugned conduct, it is indicative of how zealously the Turkish state has guarded against the influence of traditional Islam in government. See Refah Partisi (Welfare Party) $v$ Turkey App Nos 41340/98, 41342/98, 41343/98 and 41344/98 200235 EHRR 3; Boyle 2004 Essex Human Rights Review.

66 Zhurnalova Religion in the Public Sphere 334-335.

67 The German Federal Constitutional Court in deciding whether or not a school teacher was entitled to wear a headscarf in the classroom held that if the state did not order or require the dress, the religious dress could not be attributed to the state. See Ssenyonjo 2007 Chinese JIL 706. 
use state-provided education. The state should not be said to be endorsing a religion simply because it allows individuals, either employees or users of its services, to wear religious symbols. ${ }^{68}$ Lenta $^{69}$ argues that such allowances merely permit individuals to engage in what they consider to be a religiously mandated practice, but in no way require or encourage the practice.

Allowing a headscarf to be worn does not require additional state resources ${ }^{70}$ or any other positive conduct from the state and is therefore distinguishable from where the state involves itself in religion by formulating policies that require religious symbols to be displayed at schools. Allowing individuals to act in accordance with their religious convictions is arguably more in keeping with the notion of secularism than dictating whether or not individuals may wear a religious symbol which actually entails state involvement with religion. ${ }^{71}$ State policies that prohibit or mandate the wearing of a headscarf are in reality more coercive policies ${ }^{72}$ which threaten the value of secularism.

\subsection{Coercion}

Another popular justification for banning the headscarf is preventing girls from being forced into wearing the headscarf or limiting the coercive impact the headscarf may have on others who do not wear it. While the prevalence of coercion to wear a headscarf may be questionable, ${ }^{73}$ it is undisputed that where girls are forced to wear a headscarf the state should intervene to prevent such coercion. It is not clear, however, why or how a headscarf ban will prevent such coercion. The rationale

\footnotetext{
68 Lenta 2007 SALJ 310.

69 Lenta 2007 SALJ 310.

70 Human Rights Watch 2004 http://www.hrw.org/sites/default/files/related_material/ headscarf memo.pdf.

71 This is supported by Bleiberg 2005-2006 Cornell L Rev 154

72 See memorandum to the Turkish government on Human Rights Watch's concerns with regard to academic freedom in higher education, and access to higher education for women who wear the headscarf: Human Rights Watch 2004 http://www.hrw.org/sites/default/files/ related_material/headscarf_memo.pdf.24.

73 There are numerous accounts of females claiming that they voluntarily wear the headscarf and protesting against headscarf bans. See Wing and Smith 2005-2006 UC Davis L Rev 764 in which they describe the protests against the French Headscarf Ban; Welch 2007 Denning LJ 202 where Welch notes that women veil for a variety of reasons and there is no evidence to support the proposition that women wear the headscarf only due to pressure to do so; nor is there evidence to suggest that this is the reason in the majority of cases.
} 
behind a headscarf ban appears to be that girls cannot be forced to wear a headscarf if it is banned by the state. ${ }^{74}$ However, it is not clear that the perpetrators of coercion will adopt this reasoning. Individuals may nonetheless believe that girls have a choice of whether or not to wear a headscarf and whether to wear a headscarf even if it means foregoing their education. Girls may now simply be prevented from attending school or university if they are not allowed to wear a headscarf at these institutions. ${ }^{75}$ Girls who choose to attend school without a headscarf may thus still find themselves to be the victims of abuse and harassment, but this time in the form of pressure to forgo their education.

The state should prohibit the coercion itself rather than enact an obscure headscarf ban which may not achieve its purpose. Zhurnalova ${ }^{76}$ argues that a more appropriate solution to coercion is communicating with families and social service activities directed at identifying and ending the coercion of girls. The implementation of proper disciplinary measures and criminal law enforcement can also prevent coercion when in the form of harassment and abuse. ${ }^{77}$ Weil, ${ }^{78}$ however, notes that these alternative solutions, while preferable, may be practically difficult to achieve. Coercion is often hard to identify, prove and sanction, and young victims may also be reluctant to identify perpetrators for fear of being ostracised and victimised by their community. ${ }^{79}$ However, the difficulty in implementing these measures does not justify enacting a headscarf ban. The alternative measures proposed by Zhurnalova are complex and involved, but offer a real solution to what is a deeply-rooted social problem which cannot be addressed by a law which focuses on the outcome of coercion and not the coercion itself.

In respect of the coercive impact a headscarf may have on those who do not wear it, the argument is often raised and is perhaps most persuasive in a school context

\footnotetext{
Weil 2009 Cardozo L Rev 2709.

Bleiberg 2005-2006 Cornell L Rev 163.

Zhurnalova Religion in the Public Sphere 158.

Zhurnalova Religion in the Public Sphere 158.

Weil 2009 Cardozo L Rev 2707.

Weil 2009 Cardozo L Rev 2707.
} 
where a teacher wears a headscarf while teaching. ${ }^{80}$ It is the mere wearing of a headscarf by a teacher, who occupies a position of authority and acts as a role model for students, which is thought to have a coercive effect on students, and it is irrelevant whether the teacher actually says anything to promote a religious belief or influence students. The situation may be problematic as students are a "captive audience" who cannot without some difficulty escape the manifestation of religion, for instance by changing class or schools. ${ }^{81}$ The potential for coercion is heightened with young students who may be vulnerable to the views of a teacher and are more likely to emulate a teacher's behaviour. ${ }^{82}$

While any form of proselytising or coercion may be unacceptable in a school context, it is wrong to equate the mere wearing of a headscarf with proselytising or coercion. A teacher undoubtedly conveys her religious beliefs to students by wearing a headscarf, but there is nothing to suggest that being able to identify the religious faith of a teacher induces students to imitate a teacher's religious beliefs. There is no evidence in Dahlab $v$ Switzerland or any other case on the effect of wearing a headscarf on young children. The absence of real evidence as to the effect a headscarf may have on students should preclude assertions that a headscarf interferes with the religious freedom of students. ${ }^{83}$ The coercion which states must guard against is when teachers exploit their position of authority, as a representative of the school, to influence the religious beliefs of young, impressionable students. This possibility exists regardless of whether or not a teacher wears a headscarf, and a headscarf ban is a misdirected attempt by the state to guard against such coercion. Once again, authorities should focus on the coercion itself rather than the headscarf.

This argument was also raised in Leyla Sahin $v$ Turkey where the ECtHR held that the wearing of the headscarf by Sahin may have a proselytising effect and exert pressure on non-Muslims. Not only is it questionable whether Sahin, a university student herself, would be able to exert pressure on fellow university students, but the finding conflicts with the ECtHR's finding in Kokkinakis v Greece App No 14307/88 (1994) 17 EHRR 397 that proselytism is protected by the right to manifest a religion.

81 Langlaude 2006 Int'l and Comp LQ 930.

82 Dahlab v Switzerland 15.

83 Dahlab v Switzerland 15. 


\subsection{Equality}

A more peripheral argument used to justify a headscarf ban is that a headscarf is incompatible with equality and that a ban is necessary to protect the rights of women. While Weil stated that this is an unacceptable state interpretation of a religious practice which breaches state neutrality, it has been relied upon by the ECtHR in upholding the ban on the headscarf. The ECtHR, however, has never clearly explained why a headscarf is incompatible with gender equality or how the ban achieves sexual equality. The headscarf appears to be considered a sexist practice as the Qu'ran imposes it women and not men and may result in a woman's religiosity being judged according to whether or not she wears a headscarf while a Muslim man's religiosity cannot be judged by dress. ${ }^{84}$

However, most religions treat men and women differently by imposing different religious obligations on them, and such differential treatment has never justified legislative interference. For example, the Catholic Church does not allow women to be ordained as priests and in terms of Jewish law only a husband may initiate a divorce. While these are clearly sexist practices, religious adherents may nonetheless voluntarily abide by them in accordance with their religious convictions. Neither the state nor the court should prohibit practices voluntarily undertaken in accordance with religious beliefs in order to impose equality on religions.

A headscarf, however, is often treated differently from other religious practices as it is viewed as a symbol of Islam's oppression of women, which should be abolished. While Muslim women may wear a headscarf to comply with their religious obligations, a headscarf is often interpreted very differently by non-Muslims. Poulter ${ }^{85}$ notes that a headscarf is sometimes interpreted to mean that women should be inconspicuous, confined to domestic roles and completely segregated from men. Furthermore, as the Qur'anic verses quoted earlier in this article suggest that a headscarf is a means of protecting women from unwanted interferences, some feminists question why men cannot control themselves so that women can dress as 
they please. ${ }^{86} \mathrm{~A}$ headscarf is seen as isolating women and controlling the sexuality of women ${ }^{87}$ because of the inability of men to control themselves.

However, the aforegoing interpretation of the headscarf, besides breaching the requirement of state neutrality, may also be completely wrong. Muslim women are obliged to wear a headscarf only in public. Accordingly, Muslim women are not required to stay at home and restrict themselves to domestic roles but may actively participate and engage in society provided they wear a headscarf. It is without a headscarf that Muslim women are confined to their homes and excluded from society. Therefore a ban on a headscarf may actually have the perverse effect of excluding Muslim women from society and perpetuating gender inequality. This is because a ban on a headscarf has the effect of excluding females who wear a headscarf from education or employment simply because of their religious beliefs.

In fact, McGoldrick ${ }^{88}$ notes that a headscarf ban has a disproportionate effect on Muslim women and actually results in Muslim women being treated unequally. A headscarf ban requires Muslim women to forgo fulfilling a religious requirement in order to comply with the ban while their Christian counterparts can abide by the ban without sacrificing their religious obligations. ${ }^{89}$ If fairness is understood as not requiring the identical treatment of individuals but rather that individuals should be treated with equal concern and respect, 90 then a headscarf ban is unfair and unjustified. This is because a ban does not afford equal concern and respect to the religious beliefs of Muslim women who believe they are obliged to wear a headscarf.

\subsection{Religious extremism}

After the attacks on 11 September 2001 on the World Trade Centre, which were subsequently attributed to the Muslim organisation Al-Qaeda, a headscarf has also become a symbol of religious extremism. While the argument that a headscarf ban is

\footnotetext{
Wing and Smith 2005-2006 UC Davis L Rev 768-769.

Wing and Smith 2005-2006 UC Davis L Rev 768; see also McGoldrick Human Rights and Religion 13.

McGoldrick Human Rights and Religion 252.

McGoldrick Human Rights and Religion 252.

MEC for Education v Pillay 508-509 para 103.
} 
necessary to curb religious extremism is tenuous, it is nonetheless addressed as it is an emotive argument frequently alluded to in discussions on banning the headscarf.

A headscarf ban to curb terrorism equates the mere wearing of a headscarf with the holding of fundamentalist views. ${ }^{91}$ This overlooks the fact that Muslim women with no connection to terrorism may wear a headscarf to comply with the requirements of the Islamic faith. Such blatant racial profiling and prejudice should never justify a headscarf ban. Even if it is assumed that Muslim women who wear a headscarf hold extremist views, banning the headscarf does not mean that these women will cease to hold or spread these views. State action should be directed against the real threat, which is religious fundamentalism, and not against the headscarf. ${ }^{92}$ While it is easy to incite people against the headscarf on the basis of stopping terrorism, it can never in truth justify a headscarf ban.

\section{A South African perspective}

While the headscarf is becoming an increasingly contentious issue worldwide, ${ }^{93}$ South African courts have yet to encounter a headscarf ban. However, there have been a number of reported incidents in which Muslim females have been precluded from wearing a headscarf in South Africa ${ }^{94}$ and it may be just a matter of time before the legality of a headscarf ban is tested in South African courts. Courts have considered various claims for accommodation for other religious practices, which may shed light on how South African courts' would respond to a headscarf ban.

In Christian Education South Africa v Minister of Education ${ }^{95}$ an association of private schools claimed an exemption from legislation prohibiting corporal punishment from

Vakulenko 2007 Social and Legal Studies 187; Belelieu 2006 CJEL 619.

Welch 2007 Denning LJ 208.

Just recently a nursing school in Prague in the Czech Republic refused to allow two girls to wear the headscarf during classes and the Russian Supreme Court also upheld a ban on Muslim headscarves in schools. See Anon 2013 http://praguemonitor.com/2013/11/19/repekt-pragueschools-hijab-ban-request-unfortunate.

See Lenta 2007 SALJ 296. Lenta discusses the incidents where a social worker was dismissed from employment at a South African prison for wearing a headscarf and where a schoolgirl was ordered to remove her headscarf as it breached the school's uniform requirements. Also the South African Navy Dress Regulations do not make accommodation for a headscarf to be worn and may be subject to a possible constitutional challenge in the future. See South African Navy date unknown http://www.navy.mil.za/aboutus/uniform/dressregulations/index.htm. 
being administered in schools on the basis that it conflicted with their Christian beliefs and infringed on freedom of religion. The Constitutional Court held that individuals have no automatic right to be exempt from generally applicable laws on the basis of religious beliefs. ${ }^{96}$ The court emphasised, however, that the state should avoid forcing individuals to choose between complying with the law and adhering to their religious beliefs. ${ }^{97}$ The court ultimately refused the claim for an exemption because the legislation was found to serve an important interest, namely the protection of children from abuse, degradation and indignity. ${ }^{98}$ The court took seriously the fact that it was the protector of children's interests and that the child's best interests are of paramount importance. ${ }^{99}$

The Constitutional Court once again refused to grant an exemption in Prince $v$ President, Cape Law Society ${ }^{100}$ when a Rastafarian requested an exemption from drug legislation to allow him to use cannabis as part of his religious observance. The majority held that the exemption would be impossible to administer and would undermine the objectives of the legislation, being the protection of the public from the harm arising from drug use. ${ }^{101}$ Lenta ${ }^{102}$ criticised the majority's failure to consider seriously the possibility of an exemption for Rastafarians. Lenta ${ }^{103}$ noted that when a state prohibits a central practice of a religion it places a severe burden on religious adherents forcing them to contravene their religious beliefs or break the law. According to Lenta, ${ }^{104}$ such a situation is discriminatory as adherents of major religions are unlikely ever to be placed in such a predicament. While the court refused to grant the exemption in CESA and Prince, the cases illustrate that any claim for an exemption will be balanced carefully against the countervailing state interest, and religious adherents will not be allowed to rely on their religious beliefs to infringe on the rights of others or important societal goals.

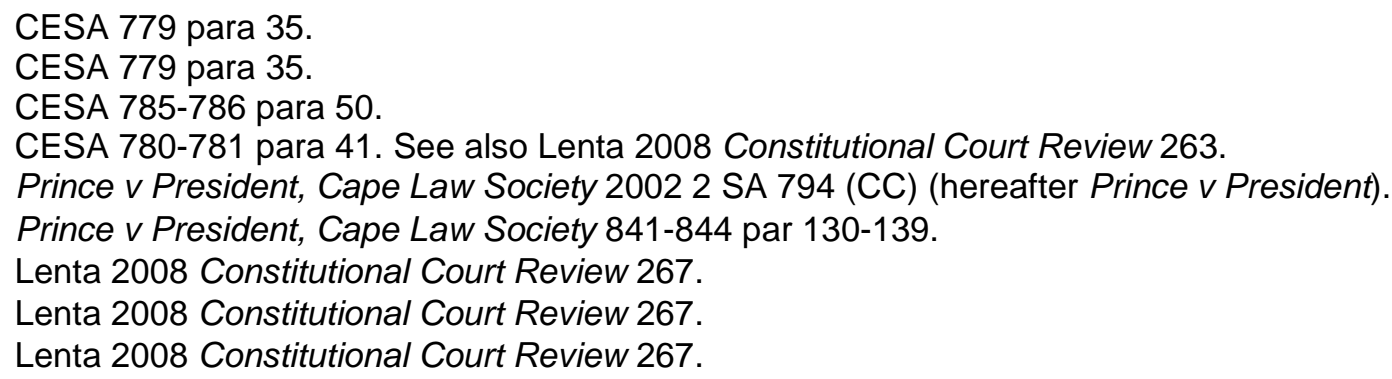


The Constitutional Court and the Supreme Court of Appeal have more recently demonstrated a willingness to accommodate religious practices. In MEC for Education, Kwazulu Natal $v$ Pillay, ${ }^{105}$ the school authorities refused to grant a Hindu pupil, Sunali, an exemption from the school dress code in order to allow her to wear a nose stud which she claimed formed part of her Hindu religion and culture. The respondent in defence of its refusal argued that an exemption would undermine discipline at the school and consequently the quality of education provided. ${ }^{106}$ While the court acknowledged that the uniform served an "admirable purpose", it held that the objective of the uniform would not be undermined by granting cultural and religious exemptions. ${ }^{107}$ The court emphasised that equality does not require treating all people the same but rather treating people with equal concern and respect. ${ }^{108}$ A uniform code without any exemptions for cultural and religious practices may relegate individuals who do not conform to mainstream social norms to the margins of society and hinder their ability to participate and enjoy their rights equally. 109

The Constitutional Court held that the school's refusal to grant Sunali an exemption constituted unfair discrimination and that the dress code should be amended to provide for the reasonable accommodation of religious and cultural practices. ${ }^{110}$ However, the Constitutional Court emphasised that exemptions would not be granted for every claim for religious accommodation and that the decision to grant an exemption would entail a proportionality analysis. ${ }^{111}$ Lenta $^{112}$ explains that the proportionality analysis entails examining whether the claimant has a genuine belief in the practice, the sincerity of the claimant and the nature and severity of the burden imposed on the claimant's religious freedom. On the other hand, the court will balance the competing interest in the application of the uniform rule and

\footnotetext{
105 MEC for Education $v$ Pillay. The claim was brought under the Promotion of Equality and Prevention of Unfair Discrimination Act 4 of 2000, but the Constitutional Court held that there may be an overlap between the Equality Act and the rights to religion and cultural life where the discrimination results from an interference with a person's cultural life

106 MEC for Education Kwazulu-Natal v Pillay 507 para 96.

107 MEC for Education Kwazulu-Natal v Pillay 508 para 101.

108 MEC for Education Kwazulu-Natal v Pillay 508-509 para 103.

109 MEC for Education v Pillay 500-501 para 73-74.

110 MEC for Education v Pillay 512 para 117.

111 MEC for Education v Pillay 501 para 76.

112 Lenta 2008 Constitutional Court Review 272.
} 
whether granting an exemption would be practically difficult to administer or undermine the objectives of the rule. ${ }^{113}$ This ensures that only genuine religious practices are accommodated and that exemptions do not create unmanageable situations for institutions to administer.

\section{In Department of Correctional Services v POPCRU 114 the Supreme Court of Appeal} considered whether the dismissal of correctional officers who wore dreadlocks and refused to cut their hair in conflict with the Department of Correctional Services' dress code was unfair. Three of the respondents explained that the hairstyle was a manifestation of their Rastafarian religion while the remaining two stated that they wore it in accordance with their Xhosa culture. ${ }^{115}$ The respondents' evidence was not disputed and in the Supreme Court of Appeal the appellant conceded that the dress code was discriminatory on religion, culture and gender. ${ }^{116}$

The appellants, however, argued that the discrimination was justifiable as it aimed to eliminate the risk and anomaly of having officers working in prisons who adhered to a religion or culture that promoted illegal drug use. ${ }^{117}$ The appellants argued that the problem was not the hairstyle but rather the Rastafarianism faith and Xhosa cultural practice, which required them to use the illegal and harmful dagga in their observance. ${ }^{118}$ The risk was that the dreadlocks made them easily identifiable and open to manipulation by other inmates to smuggle dagga into prisons which would undermine the discipline and rehabilitation of inmates. ${ }^{119}$ state school learner dress codes see De Waal, Mestry and Russo 2011 PELJ.

114 Department of Correctional Services v POPCRU 20134 SA 176 (SCA) (hereafter Department of Correctional Services v POPCRU).

115 Department of Correctional Services v POPCRU 79 para 6-7.

116 Department of Correctional Services v POPCRU 180 para 12, 182 para 18. The dress code discriminated on the basis of gender as it allowed females to wear dreadlocks and the respondents would not have been dismissed had they been female.

117 Department of Correctional Services v POPCRU 182 para 19.

118 In terms of Xhosa culture an individual wears dreadlocks temporarily in response to his ancestors call to become a traditional healer and the dreadlocks are shaved in a ceremony involving the use of dagga, signifying the individual's transition into a traditional healer. Department of Correctional Services v POPCRU 180 para 11; 182 para 19. 
The SCA noted that discrimination on a listed ground, such as religion, culture and gender, is presumed to be unfair and the employer must prove the contrary. ${ }^{120}$ In determining whether the discrimination is fair or unfair the court will consider the position of the victim in society, the purpose of the discrimination, the existence of less restrictive means to achieve the purpose, the extent to which the victim's rights had been infringed, and the impact on the victim's human dignity. ${ }^{121}$ The SCA held that the dress code had a profound impact on the respondents, as adherence to their sincerely held beliefs had cost them their jobs. ${ }^{122}$ The discrimination may, nonetheless, have been fair if it was based on inherent requirements of the job. ${ }^{123}$ The appellants, in what was a poorly argued case, failed to establish this. The appellants' oral argument, that the dreadlocks rendered them vulnerable to manipulation and corruption, was different to their argument in evidence that the dress code was necessary to entrench uniformity and neatness, which would promote discipline and security in prisons. ${ }^{124}$ Accordingly the SCA, critical of the change in argument and the lack of evidence to support the oral argument, dismissed the appeal. However, the poor manner in which the case was argued means that it is devoid of any real balancing of competing interests. It nonetheless demonstrates that the court takes seriously the balancing exercise and will not accept unconvincing and unsubstantiated arguments to justify discrimination.

In the light of the above, it is arguable that South African courts will expect schools and employers to accommodate the headscarf. ${ }^{125}$ First, the earlier discussion in this article on the centrality of the headscarf in the Islamic faith and that it is generally considered a mandatory requirement in Islam demonstrates the importance of the headscarf to Muslim females. The question of whether Muslim females will be entitled to have their religious beliefs accommodated will depend on balancing the religious interests of Muslim women against the conflicting interests in banning the headscarf.

\footnotetext{
120 Department of Correctional Services v POPCRU 182 para 21.

121 Department of Correctional Services v POPCRU 182-183 para 21.

122 Department of Correctional Services v POPCRU 183 para 22.

123 Department of Correctional Services v POPCRU 183 para 23.

124 Department of Correctional Services v POPCRU 183 para 24.

125 See also Lenta 2007 SALJ, where he convincingly argues that schools and employers are obliged to accommodate the headscarf.
} 
Secondly, the popular reasons for banning a headscarf scrutinised in this article are unlikely to justify a headscarf ban in South Africa. South Africa does not ascribe to the strict interpretation of secularism or aspire to create a single national identity for all its citizens. The South African Constitution, which provides for eleven official languages, allows religious observance in state institutions and protects both the individual and group right to culture, promotes inclusivity and accommodates difference. ${ }^{126}$ This means that the protection of secularism is unlikely to be a valid justification in South Africa. Furthermore, the connection between banning the headscarf and the goals of preventing coercion, promoting equality and curbing religious extremism is weak and does not justify the ban. This article aptly demonstrates that a headscarf ban is unlikely to achieve any of these goals.

Thirdly, with regards to prohibiting the headscarf to maintain a uniform dress code, it is arguable that an exemption for the headscarf would not undermine the objectives of a uniform dress code or be difficult to administer. Schools and employers can easily prescribe the colour and type of headscarf and the manner in which it is worn. This could very easily accommodate the religious beliefs of Muslim females and maintain the neatness and uniformity of a dress code without placing an undue burden on the institution. An exemption for the headscarf, unlike in the CESA and Prince cases, would not infringe on the rights of others or undermine the objectives of a uniform. The failure to grant an exemption would, however, hinder Muslim females who wear a headscarf from accessing education or employment and may as in the Pillay case constitute unfair discrimination. This is particularly harsh given the mandatory status of the headscarf in Islam and the ease with which it could be accommodated. FIFA demonstrated how easily the headscarf could be accommodated when in July 2012 it lifted its ban on head covers. FIFA stated that it would allow female players to wear a specially designed headscarf that satisfied their religious requirements and addressed FIFA's safety concerns. ${ }^{127}$ Sikh male players

\footnotetext{
126 For example ss 6, 15, 30 and 31 of the Constitution of the Republic of South Africa, 1996.

127 CNN 2012 http://articles.cnn.com/2012-07-06/worldsport/sport_soccer-headscarf-ban_1_ headscarf-asian-football-confederation-muslim?_s=PM:WORLDSPORT.
} 
were also allowed to cover their heads with a basic head cover in the same colour as the team jersey. ${ }^{128}$ headscarf-asian-football-confederation-muslim?_s=PM:WORLDSPORT. 


\section{Conclusion}

While a headscarf ban is hailed as a solution to a number of problems, I have sought to illustrate that a headscarf ban is not justifiable. A headscarf ban is in reality rooted in two antithetical stereotypes, namely that Muslim women need to be rescued from the oppressive Islamic faith and that Muslim women with a headscarf pose a terrorist risk to the world. In this regard, the increase in the number of laws prohibiting the wearing of a headscarf should be understood in the current political and social context. After September 11, the fear of terrorism has been translated into Islamophobia and a headscarf ban is often an attempt to suppress the Islamic practices which are viewed as threatening to Western values. The truth is that state policies that prohibit women from wearing headscarves are as problematic as state policies that compel women to wear headscarves. They hinder an individual's ability to adopt a freely undertaken practice and limit autonomy. Accordingly, I have argued that such bans are unjustifiable and South African courts if faced with such a ban should require employers and schools to accommodate the headscarf. 


\section{Bibliography}

\section{Literature}

ad-Darsh Muslim Women's Dress

ad-Darsh SM Muslim Women's Dress Hijāb or Niqāb (Islamic Book Trust Kuala Lumpur 1997)

Ahmad Encyclopaedia of Islamic Jurisprudence

Ahmad YAH Encyclopaedia of Islamic Jurisprudence Concerning Muslim

Women Vol 3 (Dar-us-salam Maktaba 2009)

Ali Meaning of the Holy Qur'an

Ali AY The Meaning of the Holy Qur'an (Amana Books Beltsville 1996)

Barbibay 2010 C/CL

Barbibay $Y$ "Citizenship Privilege or the Right to Religious Freedom: The Blackmailing of France's Islamic Women" 2010 CIICL 159-205

Belelieu 2006 CJEL

Belelieu CD "The Headscarf as a Symbolic Enemy of the European Court of Human Rights J urisprudence: Viewing Islam through an European Legal Prism in Light of the Sahin Judgment" 2006 CJEL 573-623

Beller 2003-2004 TILJ

Beller ET "The Headscarf Affair: The Conseild'Etat on the Role of Religion and Culture in French Society" 2003-2004 TILJ 581-624

Bienkowski $2010 R J L R$

Bienkowski S "Has France Taken Assimilation Too Far? Muslim Beliefs, French National Values, and the June 27, 2008 Conseil D'Ètat Decision on Mme M" 2010 RJLR 437-458 
Bleiberg 2005-2006 Cornell L Rev

Bleiberg BD "Note Unveiling the Real Issue: Evaluating the European Court of Human Rights' Decision to Enforce the Turkish Headscarf Ban in Leyla Sahin v Turkey" 2005-2006 Cornell L Rev 129-170

Boustead 2007 J Transnat'l L \& Pol'y

Boustead K "The French Headscarf Law Before the European Court of Human Rights" 2007 J Transnat'l L \& Pol'y 167-196

Bowen Why the French Don't Like Headscarves

Bowen JR Why the French Don't Like Headscarves: Islam, the State, and Public Space (Princeton University Press Princeton 2007)

Boyle 2004 Essex Human Rights Review

Boyle K "Human Rights, Religion and Democracy: The Refah Party Case" 2004 1(1) Essex Human Rights Review 1-16

De Waal, Mestry and Russo 2011 PELJ

De Waal E, Mestry R and Russo CJ "Religious and Cultural Dress at School: A Comparative Perspective" 2011 14(6) PEL/ 62-95

Fogel 2006-2007 NYL Sch L Rev

Fogel RS "Headscarves in German Public Schools: Religious Minorities are Welcome in Germany, Unless - God forbid - They are Religious" 2006-2007 NYL Sch L Rev619-653

Idriss 2005 Legal Studies

Idriss MM "Laïcité and the Banning of the 'Hijab' in France" 2005 Legal Studies 260-295

Langlaude 2006 /nt'l and Comp LQ

Langlaude S "Indoctrination, Secularism, Religious Liberty and the ECHR" 2006 Int'l and Comp LQ 929-944 
Lenta 2007 SALJ

Lenta P "Muslim Headscarves in the Workplace and Schools" 2007 SAL 296319

Lenta 2008 Constitutional Court Review

Lenta P "Cultural and Religious Accommodations to School Uniform Regulations" 2008 Constitutional Court Review 259-293

Lock "Of Crucifixes and Headscarves"

Lock T "Of Crucifixes and Headscarves: Religious Symbols in German Schools" in Hunter-Hennin M (ed) Law, Religious Freedoms and Education in Europe (Ashgate Farnham 2011) 347-369

Madani Hijab

Madani MIM Hijab: The Islamic Commandments of Hijab $2^{\text {nd }}$ ed (translated from the original Urdu and Arabic by M Sadiq) (Madania New York 2010)

McGoldrick Human Rights and Religion

McGoldrick D Human Rights and Religion: The Islamic Headscarf Debate (Hart Oxford 2006)

Mutahhari Islamic Modest Dress

Mutahhari M The Islamic Modest Dress $2^{\text {nd }}$ ed (translated by L Bakhtia) (Abjad Albuquerque 1989)

Nathwani 2007 NQHR

Nathwani N "Islamic Headscarves and Human Rights: A Critical Analysis of the Relevant Case Law of the European Court of Human Rights" 2007 NQHR 221254

Plesner "European Court on Human Rights"

Plesner IT "The European Court on Human Rights Between Fundamentalist and Liberal Secularism" Unpublished paper delivered th the Norwegian Centre for Human Rights seminar on The Islamic Head Scarf Controversy and the Future of Freedom of Religion or Belief (2005 Strasbourg, France) 
Poulter 1997 OJ LS

Poulter S "Muslim Headscarves in School: Contrasting Legal Approaches in England and France" 1997 OJ LS 43-74

Ssenyonjo 2007 Chinese J/L

Ssenyonjo M "The Islamic Veil and Freedom of Religion, the Rights to Education and Work: A Survey of Recent International and National Cases" 2007 Chinese J/L 653-710

Thomas 2005 Dialectical Anthropology

Thomas NM "On Headscarves and Heterogeneity: Reflection on the French Foulard Affair" 2005 Dialectical Anthropology 373-386

Vakulenko 2007 Social and Legal Studies

Vakulenko A "Islamic Headscarves and the European Convention on Human Rights: An International Perspective" 2007 Social and Legal Studies 183-199

Von Campenhausen 2004 BYU L ReV

Von Campenhausen AF "The German Headscarf Debate" 2004 BYU L Rev 665-700

Weil 2009 Cardozo L Rev

Weil P "Symposium: Constitutionalism and Secularism in an Age of Religious

Revival: The Challenge of Global and Local Fundamentalisms Religious Symbols in the Public Space" 2009 Cardozo L Rev 2699-2714

Welch 2007 Denning LJ

Welch T "The Prohibition of the Muslim Headscarf: Contrasting International Approaches in Policy and Law" 2007 Denning LJ 181-217

Wing and Smith 2005-2006 UC Davis L Rev

Wing AK and Smith MN "Critical Race Feminism Lifts the Veil? Muslim Women, France and the Headscarf Ban" 2005-2006 UC Davis L Rev 743-785 
Zhurnalova Religion in the Public Sphere

Zhurnalova M Religion in the Public Sphere: Public Schools and Religious Symbolism: A Comparative Analysis (PhD thesis Central European University 2007)

\section{Case law}

Christian Education South Africa v Minister of Education 20004 SA 757 (CC)

Dahlab v Switzerland Application No 42393/98 ECHR (2001)

Department of Correctional Services v POPCRU 20134 SA 176 (SCA)

Kokkinakis v Greece App No 14307/88 (1994) 17 EHRR 397

Leyla Sahin v Turkey (Application 44774/98) 45 ILM 436 (2006)

MEC for Education, Kwazulu-Natal v Pillay 20081 SA 474 (CC)

Prince v President, Cape Law Society 20022 SA 794 (CC)

Refah Partisi (Welfare Party) v Turkey App Nos 41340/98, 41342/98, 41343/98 and 41344/98 200235 EHRR 3

Syndicat Northcrest v Amselem[2004] 2 SCR 551, 2004 SCC 47

Thomas v Review Board of the Indiana Employment Security Division 45 US 707

\section{Legis/ation}

Constitution of the Republic of South Africa, 1996

Promotion of Equality and Prevention of Unfair Discrimination Act 4 of 2000

\section{International law instruments}

CCPR General Comment No 22: Article 18 (Freedom of Thought, Conscience or Religion) CCPR/C/21/Rev1/Add4 (1993)

\section{Internet sources}

AFP 2013 http://www.aljazeera.com/news/europe/2013/10/turkey-lifts-decades-oldban-headscarves-201310814177943704.html

AFP 2013 Turkey Lifts Decades-old Ban on Headscarf http://www.aljazeera.com/news/europe/2013/10/turkey-lifts-decades-oldban-headscarves-201310814177943704.html accessed 19 November 2013 
Anon 2013 http://praguemonitor.com/2013/11/19/repekt-prague-schools-hijab-banrequest-unfortunate

Anon 2013 Repekt: Prague School's Hijab Ban Request Unfortunate http://praguemonitor.com/2013/11/19/repekt-prague-schools-hijab-banrequest-unfortunate accessed 20 November 2013

CNN 2012 http://articles.cnn.com/2012-07-06/worldsport/sport_soccer-headscarfban_1_headscarf-asian-football-confederation-muslim?_s=PM:WORLDSPORT CNN 2012 Muslim Soccer Players Allowed to Wear Headscarves http://articles.cnn.com/2012-07-06/worldsport/sport_soccer-headscarfban_1_headscarf-asian-football-confederation-muslim?_s=PM:WORLDSPORT accessed 13 September 2012

Head 2010 http://www.bbc.co.uk/news/world-europe-1180622

Head J 2010 Quiet End to Turkey's College Headscarf Ban http://www.bbc.co.uk/news/world-europe-1180622 accessed 16 January 2012

Human Rights Watch 2004 http://www.hrw.org/sites/default/files/related_material/ headscarf_memo.pdf Human Rights Watch 2004 Memorandum to the Turkish Government on Human Rights Watch's Concerns with Regard to Academic Freedom in Higher Education, and Access to Higher Education for Women Who Wear the Headscarf

http://www.hrw.org/sites/default/files/related_material/headscarf_memo.pdf accessed 16 J anuary 2012

South African Navy date unknown http://www.navy.mil.za/aboutus/uniform/ dressregulations/index.htm

South African Navy date unknown Dress Regulations http://www.navy.mil.za/aboutus/uniform/dressregulations/index.htm accessed 20 November 2013 


\section{LIST OF ABBREVI ATI ONS}

BYU L Rev

Cardozo L Rev

Chinese JIL

CJEL

CJICL

Cornell L Rev

Denning LJ

ECtHR

Int'I and Comp LQ

J Transnat'l L \& Pol'y

NQHR

NYL Sch L Rev

OJ LS

PELJ

RJ LR

SALJ

TILJ

UC Davis L Rev
Brigham Young University Law Review

Cardozo Law Review

Chinese J ournal International Law

Columbia J ournal of European Law

Cardozo J ournal of International and Comparative Law

Cornell Law Review

Denning Law J ournal

European Court of Human Rights

International and Comparative Law Quarterly

J ournal of Transnational Law and Policy

Netherlands Quarterly of Human Rights

New York Law School Law Review

Oxford J ournal of Legal Studies

Potchefstroom Electronic Law J ournal

Rutgers J ournal Law and Religion

South African Law J ournal

Texas International Law J ournal

University of California, Davis Law Review 